\title{
SIRENAS CANÍBALES Y STRIPPERS EN EL CINE: LA FEMINIDAD MONSTRUOSA EN THE LURE (2015) DE AGNIESZKA SMOCZYŃSKA
}

\author{
Cristina Jiménez Gómez \\ (Universidad de Córdoba) \\ 162jigoc@uco.es
}

RESUMEN: La sirena opera como una figura cambiante, producto de las transformaciones y recreaciones que ha sufrido a través de los discursos artísticos en el tiempo, desde los relatos literarios de la Antigüedad grecolatina y el cuento de Hans Christian Andersen en 1837 hasta las artes plásticas con la pintura, escultura y arquitectura. Este estudio explora la configuración cinematográfica de la sirena en The Lure (2015) desde la mirada feminista y posmoderna de su directora Agnieszka Smoczyńska. Su film presenta dos modelos sanguinarios de sirena que, localizados en el ambiente erótico y nocturno varsoviano de los años ochenta, establecen una dialéctica con los testimonios de la tradición con el fin de cuestionarlos.

Palabras Clave: Homero, Hans Christian Andersen, sirenas, The Lure, Smoczyńska.

\section{CANNIBAL AND STRIPPER MERMAIDS IN THE CINEMA: THE MONSTROUS FEMININITY IN THE LURE (2015) BY AGNIESZKA SMOCZYŃSKA}

ABSTRACT: The mermaid functions as a changing figure, the result of the transformations and recreations that she has had in artistic discourses over time, from the literary stories of Greco-Latin Antiquity and the tale of Hans Christian Andersen in 1837 to the plastic arts with painting, sculpture and architecture. This study explores the cinematic configuration of the mermaid in The Lure (2015) from the feminist and postmodern gaze of its director Agnieszka Smoczyńska. Her film presents two bloodthirsty mermaid models that, located in the Warsaw erotic and nightlife atmosphere of the eighties, establish a dialectic with the testimonies of the tradition in order to refute them.

KEYwORDS: Homer, Hans Christian Andersen, mermaids, The Lure, Smoczyńska.

\section{INTRODUCCIÓN}

En este trabajo se pretende demostrar cómo la cineasta Smoczyńska parte de los discursos literarios de la tradición para cuestionar y rebatir la imagen de la sirena, la cual ha sido proyectada habitualmente en las artes por la mirada masculina. Tradicionalmente las categorías androcéntricas han definido la imagen femenina en los discursos artísticos en torno a la sumisión, la pasividad y la materialidad de su cuerpo. En relación a la crítica sobre la construcción de la identidad femenina en The Lure (2015), contamos con el trabajo de Martine Mussies (2018: 47-58), quien ha comparado el monstruo de Smoczyńska con el de Frankenstein en la novela de Mary Shelley de 1818. Ambos monstruos llevan a cabo un acto de cruzar las fronteras normativas y quebrantar las categorías binarias sobre las que se construye el pensamiento y el mundo, 
tales como lo masculino/femenino, público/privado, cultura/naturaleza, mente/cuerpo y humano/animal. Sobre la figura de la sirena, se apunta a que el cruce de fronteras de estas criaturas supone un cuestionamiento de las taxonomías del pensamiento patriarcal:

In other words, the discursive - let alone the corporeal - form of the Siren is inherently an instance of border crossing: both a disruption and a challenge to the rigid taxonomies of knowledge that, in turn, reflect a patriarchal mindset. [...] Border-crossing may be a legitimate practice for extending the feminist critique of the binary oppositions that underwrite patriarchy (Mussies, 2018: 53 y 56).

En este sentido, este trabajo aporta un estudio más profundo acerca de cómo la directora de The Lure rebate en pantalla esas taxonomías del pensamiento patriarcal en relación a la identidad femenina construida. La película es importante porque pone el foco de atención en dos estereotipos de la tradición literaria que han construido la identidad de la mujer como algo inamovible, fijo o estanco: aparece así la sirena a modo de femme fatale y la sirena sumisa, expectante y delicada de la tradición romántica. De esta manera, analizaremos cómo la monstruosidad, el yo femenino y la apropiación de la sexualidad de una de las sirenas rebaten el idealismo romántico y sumisión de la otra, quien, enamorada, queda reducida a la materialidad de su cuerpo por parte del varón. Esto último adquiere relevancia si tenemos en cuenta el ambiente de mercantilización del cuerpo femenino que se produce en el club de alterne donde se ubican ambas sirenas. De este modo, se cuestionan dos estereotipos sobre la «feminidad», la cual ha sido elaborada originalmente por los discursos de autoría masculina desde la Antigüedad. Como explicaba la teórica feminista francesa Hélène Cixous (1995: 15-17), los discursos tradicionalmente han definido la mujer o lo femenino siempre en términos de pasividad, naturaleza, materia, sentimiento y pathos, contrariamente a cómo se ha definido el hombre y lo masculino en torno a la actividad, cultura, forma, razón y logos. Tenemos abundantes ejemplos en la literatura, como la sufriente y siempre anhelante Penélope por la vuelta de Ulises en la Odisea y las protagonistas sumisas, durmientes y pasivas de los cuentos populares.

Más allá de los cambios formales y semánticos que supone el trasvase intermedial del texto al film en The Lure, atenderemos a los cambios pragmáticos que realiza la cineasta polaca en su film a partir de los códigos cinematográficos (palabra, música, ruidos, planos, ángulos y movimientos de cámara y decorados) y el sentido que les atribuye. Todo ello nos permitirá hablar en términos de revisión fílmica respecto a la tradición en la película de Smoczyńska. Debemos explicar que, desde su origen, el término «revisionista» ha estado estrechamente relacionado con la teoría feminista como señala Pedro J. Pardo (2010: 45-102). Anteriormente la poeta y crítica feminista norteamericana Adrienne Rich (1972: 18-30) aludió al término para advertir de la necesidad de cuestionar los textos literarios canónicos de la cultura patriarcal. Más contemporáneamente, Peter Widdowson (2006: 501) lo retoma para hablar de «ficción revisionista» o «a writing back[wards], a kind of type mirror-writing in which inverted images despict a very different reality to that authoritatively represented by the received tradition», esto es, un tipo de escritura espejo que devuelve unas imágenes invertidas muy diferentes a las que han sido representadas autoralmente por la tradición. Precisamente, en alguna de las entrevistas concedidas por Smoczyńska (Gingold, 2017), esta ha afirmado que no solo partió del cuento popular, sino también del relato homérico: «yes, we were inspired also by Homer's mermaids [in THE ODYSSEY] — the sirens that devour people. [...] Our ambition was to create a new legend, so we took 
from Homer that they eat flesh, and we took from Anderson that she loses her voice and falls in love with a man».

En su particular propuesta sobre la figura de la sirena, será significativo tener en cuenta elementos como el punto de vista desde el que se focalizan los acontecimientos, el mundo interior de las protagonistas y temas como la objetivación y mercantilización del cuerpo de la mujer, el empoderamiento femenino, la sexualidad y la relación madrehija. De esta manera, en cuanto a la estructura de este trabajo, primero realizaremos un breve recorrido por las distintas artes - literarias, plásticas y audiovisuales - que han representado la figura de la sirena, generalmente circunscrita a la muerte, la lujuria y el mito romántico del amor. A continuación, abordaremos la película de Smoczyńska para demostrar el tratamiento crítico, particular y feminista que ella realiza respecto a este motivo literario.

\section{UNA FIGURA RECURRENTE EN LAS ARTES}

La sirena es una figura mítica y universal que ha estado presente en las más variadas manifestaciones artísticas y todavía hoy seduce a muchos autores, lectores y espectadores, como es el caso de Carlos García Gual, autor del libro Sirenas. Seducciones y metamorfosis, publicado en 2014. Por ello realizaremos un recorrido por distintas disciplinas y tradiciones, como la greco-latina, romántica, eslava y cinematográfica, que han tratado la figura de la sirena.

La primera mención escrita y de forma dual a la sirena la encontramos en el siglo VIII a. C. en la Odisea de Homero. Ulises es el primero que se topa con estas criaturas después de la advertencia que le hace la hechicera Circe sobre el destino trágico que les esperaba, a él y a sus hombres, al pasar cerca de la isla donde estas criaturas habitaban. El texto homérico soslaya cualquier referencia al aspecto físico de las sirenas, pero sí explicita que son dos figuras femeninas y que su canto es letal. Posteriormente, en las Argonáuticas de Apolonio de Rodas, epopeya del siglo III a. C., se cuenta la travesía de Jasón y los argonautas en la nave Argo desde Tesalia hasta el norte de la Cólquide para obtener, con la ayuda de Medea, el ansiado vellocino de oro que le permitiría recuperar el trono y el poder. En el viaje de retorno, Jasón y los Argonautas consiguen eludir el engaño de las sirenas (mujeres-pájaro) gracias a que Orfeo, con los sones de su lira, contrarresta el canto de las criaturas aladas. Lo interesante del relato de Apolonio es el tratamiento que otorga a las sirenas porque, a diferencia del relato homérico donde escuetamente son referidas, el poeta individualiza y nombra a las sirenas - hijas de Aquelóo y la musa Terpsícore-, acentúa su feminidad asimilándolas a doncellas humanas y no alude a sus colas de pez en el texto original.

Esta caracterización física será recogida por la Eneida de Virgilio en el siglo I a. C. y las Metamorfosis de Ovidio en el año 8 d. C. También Apolodoro (Epítome, VIII, 18-19) contaba que las sirenas Pisinoe, Aglaope y Telxiepea, hijas de Aqueloo y Melpómene, además de tocar la cítara, cantar y tocar la flauta respectivamente, persuadían a los navegantes. En sus Metamorfosis el poeta romano describe a las sirenas con alas, plumas y pies de ave, aunque siguen conservando su rostro de doncellas y voz humana: «a vosotras, Aqueloides, ¿de dónde que / pluma y pies de aves, cuando de virgen cara lleváis? [...] / los virgíneos rostros y la voz humana permaneció» (Ovidio, 2002, lib. V, vv. 552, 553 y 563, p. 105). 
Estamos, pues, ante la mujer ave que seduce con su canto y música a la vez que se revela letal para el varón, lo que también se representó previamente en las artes plásticas a través de mortíferas mujeres-pájaro músicas, con rostro de mujer y senos desnudos en piezas de cerámica corintias y en monumentos y ofrendas funerarios hacia el año 560 a. C. Sin embargo, progresivamente, las alas, garras y plumas irán cediendo paso a las escamas y la cola de pez, aunque siempre vinculadas al mundo de los muertos. En el siglo I o II a.C. ya aparece alguna estatua en piedra con la forma de la mujer medio pez en ritos funerarios de damas de la alta alcurnia helénica.

En el Medievo la primera manifestación escrita sobre las mujeres-pez aparece en el siglo IX d. C. en el bestiario Liber monstrorum de diversis generibus, atribuido a Aldhelmo de Sherborne: «Desde la cabeza hasta el ombligo tienen cuerpo de mujer, pero tienen las colas escamosas de los peces» (Elvira, 2008: 134). También aparecerá la sirena-pez de dos colas especialmente en las formas escultóricas de los pórticos y capiteles románicos castellanos, respondiendo mejor a los cánones de simetría de la época. Según algunos autores, ${ }^{1}$ la sirena bifurcada o con cola bífida se pone en relación con la mujer lujuriosa, prostituta y exhibicionista puesto que las dos colas, en correspondencia con las dos piernas humanas femeninas, aparecen levantadas mostrando los genitales (Fig. 1).

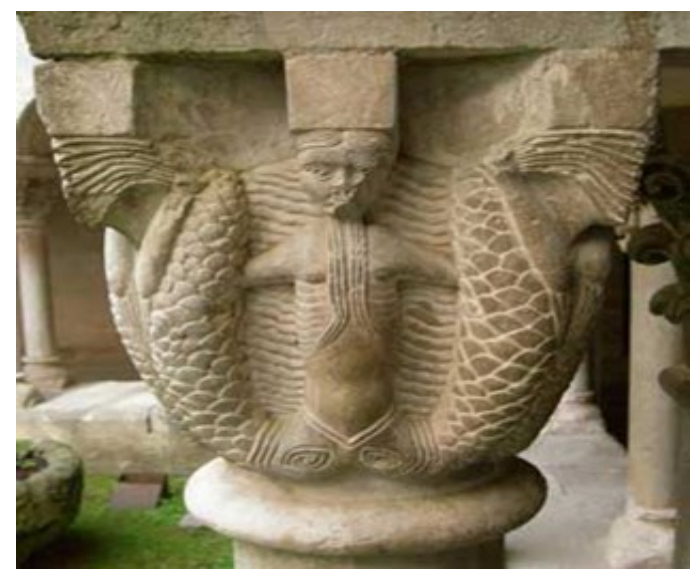

Figura 1. Capitel en iglesia Sans Pere de Galligans

(Girona, 1130)

Las sirenas mitad pájaro y mitad mujer con un instinto asesino en los bestiarios medievales pasarán a ser conceptualizadas como peligrosas y pecaminosas rameras bajo el Cristianismo. Como explica $\mathrm{M}^{\mathrm{a}}$ Consolación Isart (1994: 25-42), desde el siglo II d. C. los Padres de la Iglesia tomaron la figura de Ulises como un ejemplo de la fortaleza moral frente al pecado y la lujuria de las sirenas pisciformes, que se convierten en el arquetipo de las prostitutas. Recordemos que ya Horacio en sus Epístolas, publicadas entre los años 20 y 14 a. C., también elogiaba a Ulises y vinculaba a las sirenas con Circe, definida como la hechicera prostituta: "Conoces el canto de las sirenas y los bebedizos de Circe; de haberlos bebido, insensato y ávido, como sus compañeros, hubiera caído, deforme y bruto, bajo el yugo de aquella ramera» (2002, I, vv. 23-25, 17 $18)$.

${ }^{1}$ F. Cana en Iconografía del románico burgalés (1992) asimila la sirena, formal e icónicamente, a la mujer exhibicionista, con sus dos piernas levantadas y mostrando su sexo, que también forma parte del repertorio habitual en canecillos y capiteles. 
Por consiguiente, muy pronto la sirena fue asociada al pecado y la tentación de la carne sirviendo así a los fines moralizadores de la Iglesia. En la Edad Media San Isidoro de Sevilla recoge a la sirena prostituta en sus Etimologías cuando afirma que «en verdad, las sirenas eran meretrices, y los navegantes que pasaban por allí, impelidos a gastarse lo que llevaban, tenían que fingir un naufragio» (1951, lib. XI, cap. 3, 30-31). Asimismo, en el año 1220, el filósofo y humanista Brunetto Latini asocia la figura de la sirena con la prostituta en Le Livre du trésor, del cual contamos con un manuscrito traducido al castellano en el siglo XV: «las sirenas fueron tres meretrices que engañaban a todos los que se cruzaban en su camino y los arruinaban» (pp. 131-132). En el siglo XIV Boccaccio, en su Genealogía de los dioses paganos, compara a las escurridizas y rápidas sirenas que nadan en el agua con la celeridad de las meretrices para unirse sexualmente a varios hombres: "son animales escurridizos y que corren con facilidad por las aguas de un lado a otro, así también vemos que las meretrices corren a la unión sexual de varios» (Boccaccio, 1983, VII: 19-20). Incluso los pintores victorianos del siglo XIX, como Herbert Draper con La doncella marina (1894), recrearon a las sirenas prostitutas. En algunas de estas obras podemos encontrar a las sirenas desnudas, sin cola $\mathrm{y}$ encaramadas a las redes de los pescadores o en acantilados rocosos recibiendo oro y joyas como regalo de un grupo masificado de hombres, por ejemplo en La leyenda de Kerdeck (1890) del pintor francés Fernand LeQuesne.

No obstante, el siglo XIX estará marcado por la representación predominante de la sirena enamorada y apacible en manos de los pintores románticos, quienes rehuyeron el tratamiento y fondo mítico para representar a hermosas sirenas silentes que atraían hacia el amor en medio de los ríos ingleses y alemanes según explica Gual (2014: 23). En este contexto, nos encontramos incluso con algunas pinturas donde aparece la humanización completa de la sirena, que ha trocado la cola por dos piernas, por ejemplo en El pescador y la sirena del pintor sueco Knut Ekwall, establecido en Munich desde 1870, y en El beso de la sirena de Gustav Wertheimer en 1882. Son mujeres misteriosas y de gran erotismo que, con y sin cola, representan el amor, la vanidad y la feminidad. Un ejemplo es la conocida imagen prerrafaelita de la sirena peinándose de J. W. Waterhouse en 1901. En esta época, es frecuente que aparezcan empuñando un peine en la mano derecha y un espejo en la siniestra en lugar de un arma o un instrumento musical como en la Antigüedad.

Vemos, pues, que la sirena mortal y seductora se desdibuja en un período que coincide con la publicación del cuento popular de Hans Christian Andersen en 1837, el cual, como afirma Maceiras (2014: 211), «ha condicionado en gran medida la recepción del mito en el presente a través de sus múltiples ecos en la literatura y el cine, ya que introduce un tema esencial en la configuración actual de la sirena: el amor». Aparece la búsqueda del amor como objetivo prioritario, aunque suponga la renuncia de su vida acuática, su identidad y su voz. Es una propuesta que, con un edulcorado final, ha recogido el arte cinematográfico en más de una ocasión con la conocida adaptación animada La Sirenita de los estudios Disney en 1989, dirigida por Ron Clements y John Musker, o el film Un, dos, tres... Splash, dirigida por Ron Howard en 1984. En el primer caso, la muerte de la sirena por el amor no correspondido que se recogía en el cuento de Andersen se transforma en un final dichoso en la producción infantil de los años noventa, la cual ha sido revisada contemporáneamente en 2019 con la propuesta de una sirena afroamericana. En el caso de la exitosa comedia romántica y fantástica de Howard, producida por Touchstone Films, el romance polariza todo lo demás. Se presenta una sirena (Daryl Hannah) ingenua, ignorante y que se asimila pronto y sin dificultad a la vida del protagonista masculino (Tom Hanks), olvidando su identidad y 
su mundo de pertenencia. En momentos del film la sirena también queda representada de forma fragmentada y metonímica a través del enfoque de la cámara de distintas partes de su cuerpo.

Asimismo, una de las conceptualizaciones, entre otras, que representan lo femenino en el cine es la dualidad vida/muerte, como podemos ver en el personaje de la femme fatale del cine negro o film noir de los años cuarenta del siglo XX. En este sentido, el cine de terror contemporáneo también evoca ese estereotipo de la mujer fatal en la mujer monstruo en tanto que su acción y seducción resultan amenazantes o mortales para el varón. En este género cinematográfico, la sirena siempre va acompañada de la belleza y la fatalidad, características que según Joaquín Carlos Martín (2010: 39-40) permiten hablar de la femme fatale más allá de que muchos autores delimiten esta figura al cine negro hasta finales de la década de 1950. Recientemente nos encontramos con la evocación de esta sirena a modo de femme fatale en películas como Mermaid (2019), dirigida por el ruso Svyatoslav Podgayevskiy. Lo particular de la sirena de este director, que también dirigió La novia (Hebecta, 2017), es que no tiene una cola de pez, es una pseudosirena cuya imagen procede de la tradición popular eslava a través del mito de la rusalka, ${ }^{2}$ la ninfa del agua que seducía a los hombres para matarlos.

Si bien hay variaciones, la mayoría de las leyendas del folklore eslavo relaciona a las rusalki, plural de rusalka, con un deseo veladamente sexual y bastante perverso debido principalmente a la soledad y el resentimiento por parte de las rusalki hacia los varones humanos. La razón se debe a que perdieron su condición de humanas y se volvieron rusalki, criaturas que habitan en el agua, debido a un amor desgraciado o no correspondido en el pasado. Por ello, el acto de seducir de estas criaturas se vuelve vengativo hacia el varón en muchos testimonios escritos de la cultura popular eslava como explica Francisco Molina (2017: 101-142).

Más allá de la tradición popular, la trama de Podgayevskiy no solo deja ver la figura de la rusalka a modo de femme fatale que seduce al varón, sino que también proyecta en pantalla la disputa femenina entre la miedosa humana Marina, con fobia al agua, y la criatura que habita en sus profundidades y desea arrebatarle a su prometido. En relación con esta rivalidad femenina por el varón, la teórica mexicana Marcela Lagarde (2012: 461-491) explica que la competencia histórica entre las mujeres se construye y perpetúa en el patriarcado dado que estas solo pueden obtener la existencia social en su relación con los hombres: primero, a través del padre con el reconocimiento filial cuando es niña y, segundo, a través del marido con el vínculo de conyugalidad cuando es adulta. Por ello, cada mujer se convierte en una potencial enemiga para la otra en un mundo donde el reconocimiento social, jurídico y cultural viene dado por el varón.

Tras este recorrido por las artes, comprobamos cómo la sirena, representación de la «feminidad» en los discursos, ha sido supeditada a determinadas imágenes como la seductora y mortífera femme fatale y la amorosa y sumisa mujer. Esta última guarda

\footnotetext{
${ }^{2}$ Francisco Molina (2017: 101-142) realiza un interesante estudio sobre la vida amorosa de las rusalki. Estas figuras, que pasaron de la tradición oral a la escrita en la cultura eslava oriental de los siglos XX y XXI, también están sujetas, como las sirenas, a variaciones y transformaciones en los discursos patriarcales a lo largo del tiempo. Nos encontramos así con la rusalka que sale de la orilla a peinar sus cabellos; la rusalka con falta de «instinto maternal» que mata a los niños nacidos de su unión con el hombre; la rusalka que seduce a hombres incautos, solitarios y tontorrones; y la rusalka cristianizada gracias al bautizo otorgado por un cura, de modo que la criatura se redime y se vuelve humana en un discurso con un obvio fin moralizador.
} 
relación con «el ángel del hogar» de la literatura decimonónica. Sobre este tema Bram Dijkstra en su libro Ídolos de perversidad. La imagen de la mujer en la cultura de fin de siglo (1994) explora la abundancia de discursos pictóricos, filosóficos, literarios, científicos y morales que, a finales del siglo XIX, construyeron la imagen femenina. Esta siempre se relaciona bien con la sumisión, la obediencia y la maternidad sagrada - recuérdese la Virgen con Niño entronizada (1433) de Van der Weyden-, o bien, con el erotismo, el poder y la belleza mortal como las mujeres bíblicas Judith, Dalila y Eva; la poderosa y bella Cleopatra en la historia de Egipto; y mitos femeninos caracterizados por la perversidad, como Medusa, las Sirenas y las Harpías.

En este contexto, la sirena fílmica de Agnieszka Smoczyńska en The Lure (2015), su ópera prima, cuestiona las representaciones dadas a esta figura en las artes. Su película parte de la tradición literaria, greco-latina y romántica, para realizar, como veremos, una revisión crítica colocando en primer plano el cuerpo, la sexualidad y el yo de la mujer en la Varsovia comunista de los años ochenta.

\section{LAS «HIJAS DEL BAILE»: HETEROGENEIDAD Y DUALIDAD EN THE LURE}

El título original en polaco de la ópera prima de Smoczyńska, Córki dancingu («hijas del baile» o «hijas de la discoteca»), pierde su significativa carga semántica en la traducción que posteriormente se realizó para la entrada del film al mercado cinematográfico internacional. En este sentido, pero en el ámbito literario, Manuel Martínez (2003: 105-106) resalta que el autor, con la elección de sus títulos literarios, marca pautas o directrices a través de sus niveles isotópico-semánticos, semiológicos y pragmáticos. El título cinematográfico The Lure, que se traduce como «el señuelo», no esboza la evidente intencionalidad de la cineasta de alejarse de las figuras míticas meramente mortíferas, tramposas y seductoras con que se topó Ulises a su vuelta a Ítaca o de buena parte de las sirenas retratadas en la tradición fílmica de los siglos XX y XXI. El hecho de presentar a la sirena como una stripper cantante en la Polonia de la década de los años ochenta pone el foco de atención en la explotación sexual de la mujer y en su conceptualización como objeto de deseo del varón y no como sujeto. Las sirenas de la directora polaca se distancian también así de la imagen benevolente y pasiva del cuento andersiano a través de un espacio nocturno y habitual - los restaurantes con espectáculos eróticos - en la Polonia de los últimos años de 1980. Es un momento en que el poder de la Iglesia católica y el capitalismo occidental suponían una amenaza creciente para el régimen comunista.

La ubicación de la figura femenina pisciforme en la Varsovia nocturna de los años 80, bajo la imagen dual de dos hermanas sirenas adolescentes, permite a Smoczyńska presentar la heterogeneidad y diversidad en su film. Esto se puede observar desde la primera escena. Durante la oscuridad de la noche, la cámara se acerca a la superficie del agua del río Vístula, donde emergen dos sirenas con un canto seductor que repiten la frase «pescadnos, no mordemos» (Fig. 2). Es un canto que parece resonar durante unos segundos eternos en los oídos de los dos hombres integrantes de una banda musical quienes, junto a otra cantante, están cantando, tocando música y celebrando una barbacoa en la orilla. 


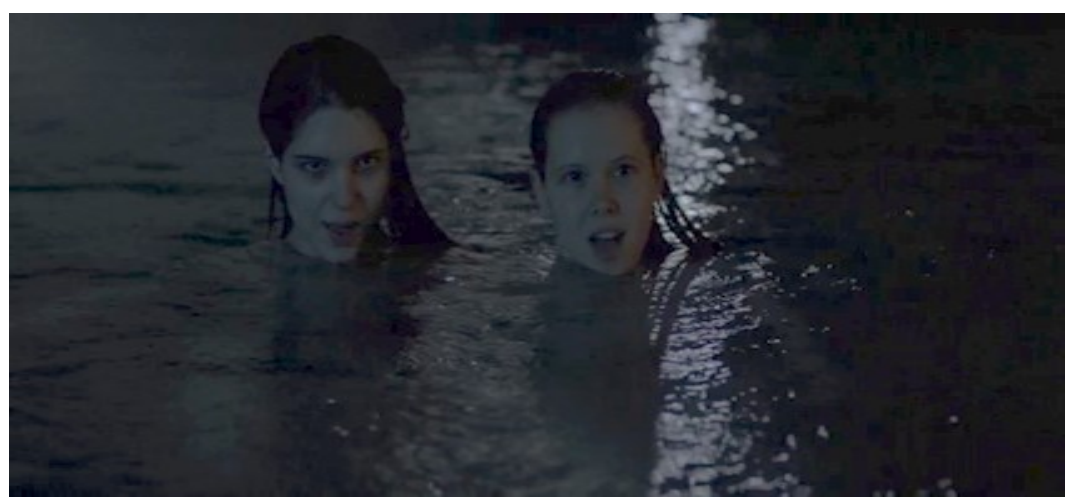

Figura 2. Golden y Silver

El contraste entre lo apolíneo y lo dionisíaco en las sirenas, entre sus angelicales rostros y colas monstruosas, es recogido desde las primeras secuencias del film en aras de no solo generar desconcierto y terror en el espectador, sino también de plasmar el poder y la fuerza de estas enigmáticas criaturas. Surgen así imágenes tan potentes como la de la criatura acuática, brutal, enigmática y poderosa, con un trozo de carne humana, que se arrastra gracias a su cola inmensa, mucosa y con olor a cieno por la arena hasta llegar al agua (Fig. 3). La sirena en The Lure no es tan solo nauseabunda, terrorífica y sanguinaria (Fig. 4) a ojos del espectador, sino también poderosa e insurrecta.

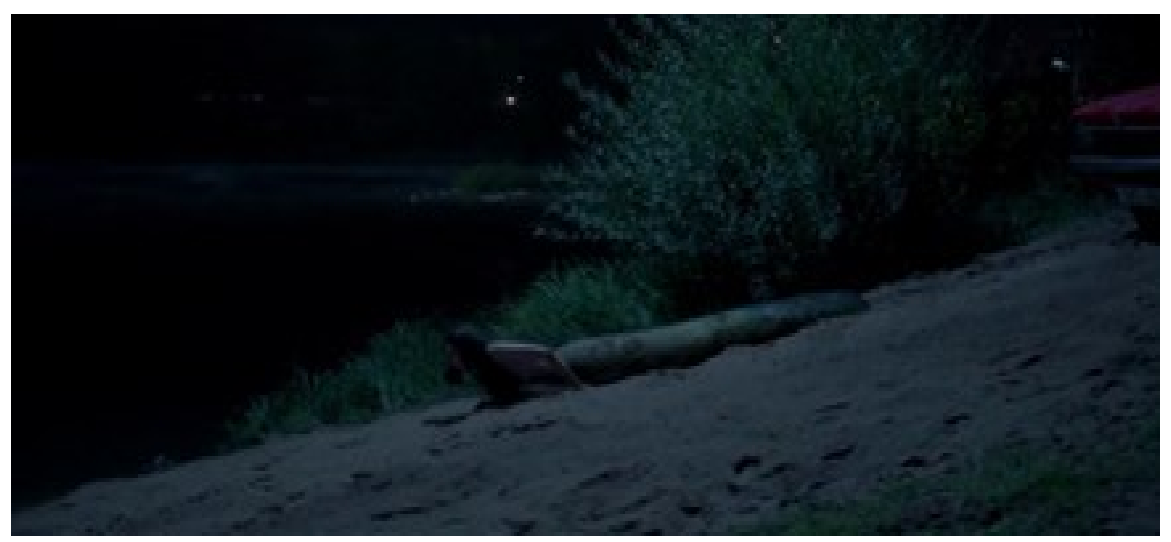

Figura 3. Golden

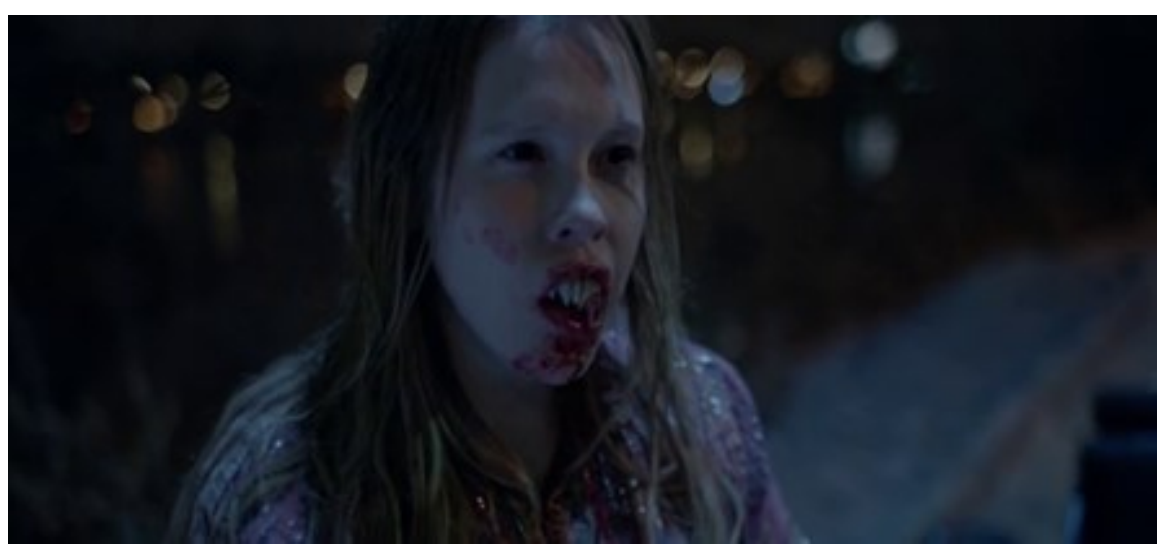

Figura 4. Silver 
Así pues, en la primera escena, la cámara nos muestra un plano subjetivo donde vemos al grupo de humanos en la orilla a través de los ojos de las sirenas. Es de noche, la sutil neblina envuelve el entorno del río Vístula, los músicos de un bar beben y cantan en la orilla y la cámara se acerca a la superficie del agua de donde emergen dos jóvenes hermanas sirenas, Golden (Michalina Olszańska) y Silver (Marta Mazurek), que fijan su mirada en la banda musical compuesta por la cantante Krysia, el baterista y el joven bajista Mietek. En medio de una barbacoa nocturna, los dos varones se sienten fascinados por el canto melodioso y seductor de las dos sirenas y se aproximan al agua. Solo el chillido despavorido de Krysia les hace despertar de la fascinación y, enseguida, nos traslada a las luces, brillos y el ambiente discotequero del club nocturno donde trabajan, un lugar de «entretenimiento para adultos» como dice su mánager. Es un espacio donde se reclama el cuerpo de la mujer en un manifiesto proceso de objetivación, apropiación y mercantilización masculina.

Desde la primera secuencia, las aguas negras y enigmáticas del río Vístula, pronunciadas por la oscuridad de la noche, se tornan precipitadamente en luces de neón, colores chillones y música disco estridente en la escena que le sigue. Las criaturas acuáticas son llevadas al club nocturno y mostradas al mánager, quien pronto vislumbra el beneficio económico que podría ocasionarle la exhibición del cuerpo monstruoso y a la vez seductor de las dos sirenas. Ellas, curiosas por ese mundo humano tan distinto al suyo, se convierten en el reclamo de un espectáculo en el que cantan, bailan y, además, se mueven semidesnudas dentro de enormes copas llenas de agua (Fig. 5).

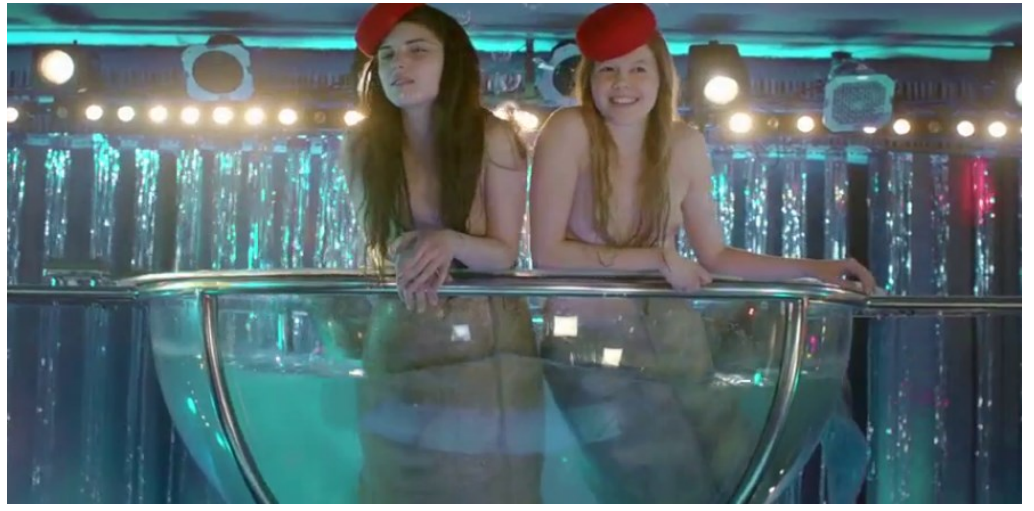

Figura 5

La caracterización fílmica de Smoczyńska, muy alejada del ideal clásico de Andersen, consigue captar la atención del espectador contemporáneo desde el primer momento. No obstante, la cineasta ha querido plasmar en pantalla dos personalidades y dos identidades muy distintas, produciéndose así la dualidad en torno a la figura de la sirena que dialoga con los dos modelos dominantes de la tradición literaria. Silver es una complaciente y dulce sirena que se enamora del guitarrista Mietek y anhela adquirir no solo unas piernas humanas permanentes, que no muden en cola de pez al mojarse, sino, sobre todo, una vagina. Esta es la condición del bajista Mietek para poder estar con ella y verla, según dice, como una mujer y no como animal. Así, ella es definida por sus genitales y convertida en pura materialidad, lo que acabará ocasionándole no solo la pérdida de su voz y su identidad, sino también su muerte. En cambio, Golden, segura, decidida y de fuerte carácter, no establece ningún tipo de interacción afectiva con los humanos varones y disfruta devorándolos. Su deseo es seguir el plan establecido, 
alcanzar nadando los Estados Unidos y regresar al agua, al mundo donde pertenece lejos del ambiente erótico-musical de la ciudad de Varsovia.

A este respecto, la heterogeneidad genérica en la que se inscribe la película, vinculada al mismo tiempo con lo fantástico, el terror, la comedia romántica, el musical y el thriller, plantea no solo un quehacer ecléctico por parte de la directora, sino también una estética para desmontar y parodiar los géneros de la tradición, las fantasías masculinas, la imagen de la mujer objeto y el mito del amor romántico. Los números musicales de vibrante ópera rock, disco y techno pop se integran en una estética glampunk de lentejuelas, luces y atuendos de colores chillones, en medio de una breve historia de romance y las prácticas caníbales de unas sirenas investigadas por una detective. A partir de esta complejidad formal, genérica y semántica, se trasluce la mirada crítica de Smoczyńska en base a la mostración y explotación del cuerpo femenino, la prevalencia del deseo del hombre y unos parámetros que solo hacen visible a la mujer a través de la mirada masculina. Cixous (1995: 14) definía estos parámetros sobre los que se ha asentado el pensamiento universal como «oposiciones duales y jerarquizadas».

Muy pronto comprendemos que el film establece una denuncia de estos parámetros u oposiciones duales y jerarquizadas en torno a la pareja hombre-mujer. La brutal y sanguinaria acción de Golden se revelará con más fuerza cuando su hermana Silver se disipe, convertida en espuma de mar, al ser rechazada por el bajista Mietek. Silver terminará matando al músico en un acto sangriento donde la sirena se abalanza sobre la yugular del joven en la escena final del film. De esta manera, Smoczyńska pone el foco de atención en plasmar y cuestionar en pantalla los dos modelos de la tradición literaria que han recreado la figura de la sirena por antonomasia. Si Golden se vincula con la destructora ${ }^{3}$ sirena homérica, la enamoradiza Silver se relaciona con la sirena cuentística de Andersen, representando el falso ideal del amor romántico que ocasiona su muerte y la pérdida de su identidad, cuerpo y voz. En la mostración de estos elementos y motivos es donde se evidencia la asunción de un punto de vista crítico por parte de la directora.

\section{EL USO DE LA MÚSICA Y LA MIRADA FEMENINA}

La música será un elemento significante para proyectar la mirada femenina acerca de temas como la identidad, la sexualidad y la exploración del yo en la mujer. De esta manera, la directora polaca contrarresta una tradición cinematográfica donde la imagen de la mujer, en general, y de la sirena, en particular, se ha construido en relación al protagonista masculino. En la historia del cine el hombre ha sido el portador de la mirada dentro y fuera del film como explica la teórica de cine Laura Mulvey en su ensayo Visual Pleasure and Narrative Cinema de 1975. Mulvey parte de las teorías del psicoanálisis de Freud y Lacan para demostrar cómo el cine clásico hollywoodiense de las décadas de 1950 y 1960 colocaba al espectador en una posición de sujeto masculino en tanto que se proyectaba bajo la mirada de un director y de unos protagonistas que eran eminentemente masculinos. Mientras que el espectador y el protagonista

3 Renata Salecl (2002: 73) explica que las antiguas sirenas de la mitología clásica, mitad humanas y mitad pájaros, se identifican con el puro deseo, por un lado, y con la muerte, por otro, lo que conlleva el desgaste del Patriarcado. Las sirenas representan un peligro no solo para la vida particular de los hombres, sino también para el orden social impuesto por ellos, esto es, la estructura familiar. El varón, tras su encuentro con las criaturas marinas, nunca más regresa al núcleo familiar, con su esposa e hijos. 
masculinos son los portadores de la mirada, la mujer se construía como el objeto de la mirada masculina voyerista: «Tradicionalmente, la exhibición de la mujer ha funcionado en dos niveles diferentes: como objeto erótico para los personajes de la historia que se desarrolla en la pantalla y como objeto erótico para el espectador que se encuentra entre el público, con una tensión variable entre las miradas de cada lado de la pantalla» (Mulvey, 2001: 371).

La identificación de las mujeres ante la pantalla pasa, entonces, por asumir una posición pasiva — ser mirada - y unos patrones que exaltan la debilidad y sumisión femeninas o que censuran comportamientos que van en contra de la norma en personajes como la prostituta y la mala madre. Sin embargo, en The Lure, se produce un cambio de mirada. Ahora la que observa y exterioriza su punto de vista es la mujer, representada por las sirenas dentro del relato cinematográfico y por Smoczyńska fuera del mismo. Gracias al uso connotativo de la música se representa en pantalla la perspectiva de las sirenas acerca del mundo humano que les rodea y al mismo tiempo se proyecta la mirada crítica de la directora. Al ritmo de los hits discotequeros de los años ochenta como el I feel love de Donna Summer, interpretado por la cantante del grupo Krysia, se desmitifica el ideal del amor heterosexual que supedita a la mujer a la espera del varón y a convertirse en el objeto del deseo masculino. De la misma manera se realiza una parodia de las fantasías sexuales masculinas que se fundamentan en el fetichismo y la objetivación de la mujer, por ejemplo cuando las sirenas aparecen convertidas en conejitas Playboy durante una sesión fotográfica (Fig. 6) o en azafatas de avión durante uno de los espectáculos musicales en el club.

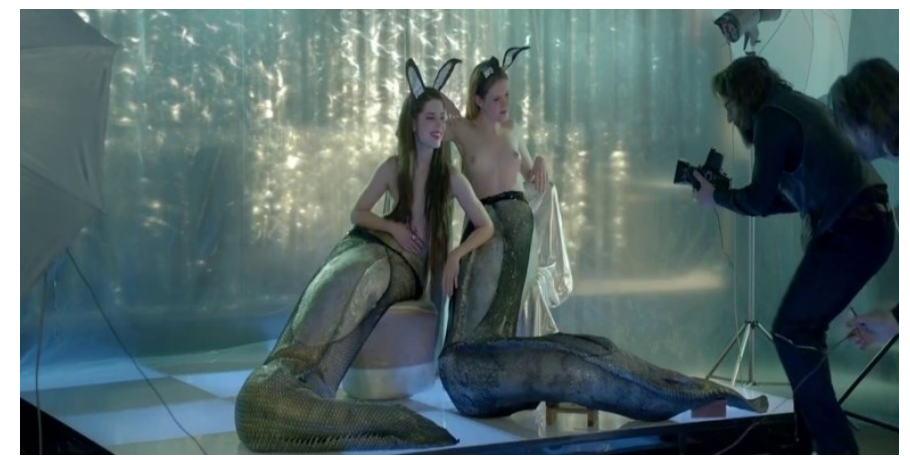

Figura 6

En este contexto, la música diegética no es utilizada únicamente como simple ilustración de la acción, sino que es un elemento imprescindible para plasmar el mundo interior de las protagonistas, sus pensamientos, deseos y sexualidad. Además de los hits ochenteros, las canciones del grupo Ballady i Romanse, dúo polaco compuesto por las hermanas Zuzanna y Barbara Wronska, permiten traducir la intimidad psíquica en pantalla y la perspectiva desde la que las sirenas observan el mundo. Por ejemplo, al principio del film, vemos el desarrollo emocional de las sirenas ante el descubrimiento de la gran ciudad, lo que se plasma en sublimes momentos de comedia musical (Fig. 7) a partir de la canción I came to the city, la luminosidad y el cromatismo vivo y dinámico en el centro comercial Sezam. 


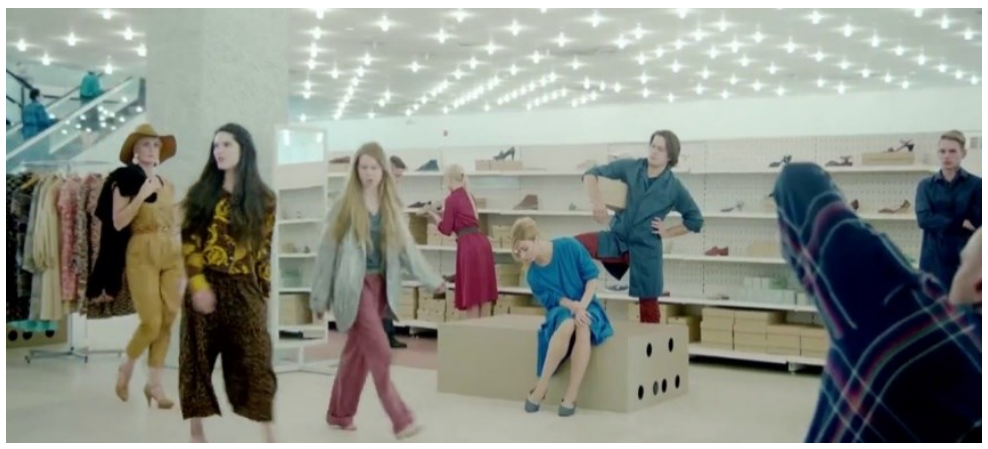

Figura 7

Así pues, aparece la autorreflexión cuando ambas están descubriendo la ciudad en medio de la vorágine de los vehículos y el bullicio de la gente a causa del consumismo en el centro comercial. Las sirenas cantan y repiten «la ciudad nos dirá lo que nos falta» expresando así la necesidad de conocerse a sí mismas en una etapa vital, la adolescencia, que también conlleva descubrimientos en el terreno de la sexualidad. En este caso, mientras que el encuentro sexual de Silver con Mietek conlleva la amputación de su cola, la pérdida de su voz e identidad, un estado de semi invalidez y la muerte, Golden explora una sexualidad libre y no sujeta a patrones heteronormativos patriarcales. La primera elimina su cola para que le sean trasplantadas las piernas y genitales de una humana en aras de ajustarse a las condiciones impuestas por el joven Mietek. En cambio, la segunda experimenta unas prácticas lésbicas y sadomasoquistas con una mujer humana policía en una escena donde la cola se convierte en un elemento placentero y fetichista.

En esta transición de una escena a otra vemos un cambio de tono y género musical puesto que, de una performance desenfadada, cantada y bailada coreográficamente por los clientes del centro comercial a modo de comedia musical, pasamos a la canción electrónica «Mujer policía», más oscura, intimista, y cantada a dúo por Golden y la mujer policía. La letra está cargada de sensualidad: «los cuerpos retozan con emoción, veremos juntas arder París». En ese momento Golden y la policía que investiga sus crímenes cantan y recorren la ciudad en auto por la noche. El ambiente se torna cada vez más erótico y la escena termina en una habitación donde la monstruosidad de la sirena es observada como algo placentero por ambas (Fig. 8).

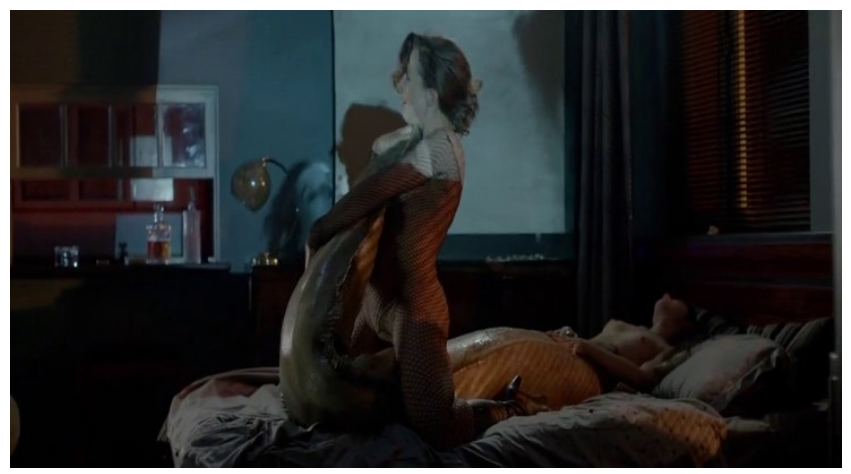

Figura 8

Aparece así una sexualidad femenina exenta de la mirada voyeur masculina y ahora la sirena se representa como el sujeto de deseo y no como objeto. En su obra Ese 
sexo que no es uno, Luce Irigaray (2009: 17) explicaba que «la sexualidad femenina siempre ha sido pensada a partir de parámetros masculinos» y supeditada al deseo del hombre, no al suyo, olvidando su propio placer. Tal y como está construido el discurso fílmico en The Lure, se rebate la preponderante mirada masculina que históricamente ha plasmado el cuerpo y la sexualidad de la mujer en pantalla. A través de la sirena Golden, Smoczyńska devuelve el poder de la mirada a la mujer, quien toma el control de su cuerpo, sexualidad y placer.

\section{LA TRADUCCIÓN DE LA INTIMIDAD FEMENINA EN PANTALLA}

Desde las sirenas mujer-pájaro de la Antigüedad grecolatina hasta la bondadosa y servicial doncella con cola de pez del cuento de Andersen, la figura de estas misteriosas criaturas generalmente ha aparecido, en textos literarios y fílmicos, reducida a lo físico, la materia. En el film de Smoczyńska, se produce la imposibilidad de materializar el deseo sexual masculino en unas sirenas que, en su forma humana, no poseen genitales femeninos y que, en su caracterización pisciforme, disponen de una hendidura maloliente en su cola. Vemos, así, los cuerpos asexuados de las sirenas en unas escenas que de inmediato provocan en el espectador un grado de intimidad al que no estamos habituados y que es descrita por el baterista de la banda: «son lisas como muñecas Barbie» (Fig. 9). De esta manera, el sexo de la mujer es definido siempre en relación con el deseo del varón; por eso, el sentimiento amoroso de Silver, sin sexo, encuentra una respuesta negativa en Mietek en un primer momento. Al no poseer unos genitales femeninos, el joven no puede contemplarla como mujer, motivo por el que la sirena se somete a un procedimiento quirúrgico en una de las escenas más impactantes y crudas del film: la amputación quirúrgica de su cola de pez y su reemplazo por unas piernas y genitales procedentes de una mujer humana viva (Fig. 10).

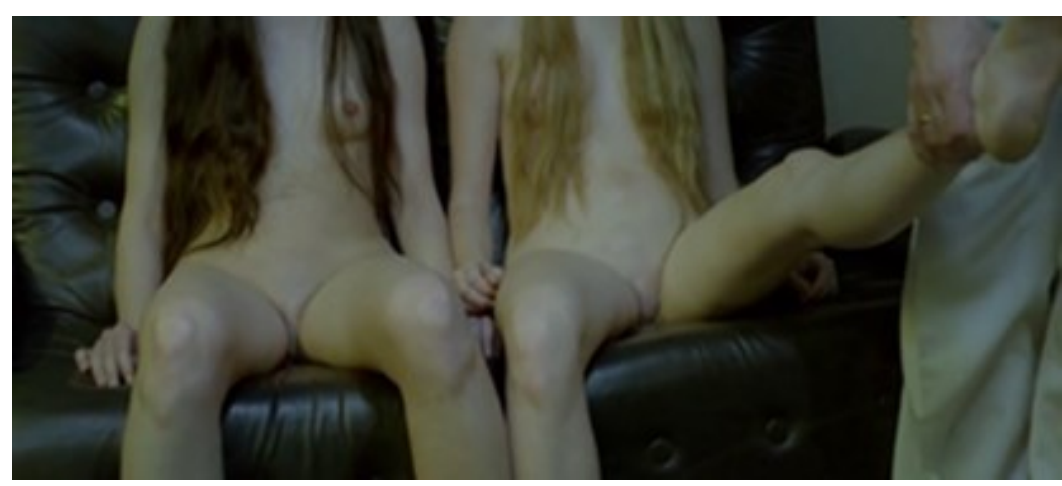

Figura 9 


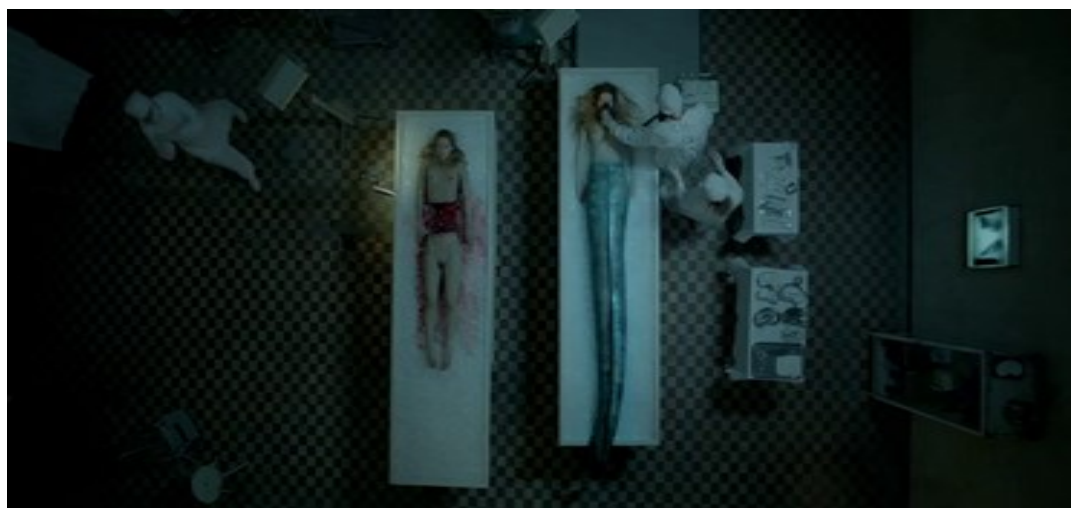

Figura 10

A través de Silver, la directora expresa la objetivación y pérdida de la identidad que sufre la sirena en pantalla. Silver desea no tanto poseer piernas humanas como la protagonista andersiana, sino una vulva que consiga que Mietek pueda estar con ella. Queda así circunscrita únicamente a su cuerpo, su sexo, que es el que la define como mujer en la sociedad.

La utilización del plano cenital justo encima de las dos figuras femeninas, una humana y otra pisciforme, consigue crear una imagen de gran efecto en el espectador, quien se adentra en el patetismo y la angustia de ambas. El plano cenital extrapola la técnica narrativa del narrador omnisciente en pantalla permitiéndonos, como espectadores, no solo observar en una posición privilegiada todas las acciones que ocurren en un pseudoquirófano, sino también ser testigos del sufrimiento de la sirena cuya cola está siendo amputada. De esta manera, el plano cenital deja ver una extensión amplia del lugar coloreado de tenues tonos azulados que exteriorizan el mundo interno de la sirena mientras el cirujano y sus ayudantes manipulan y cercenan los cuerpos de la criatura y la humana. Poco después, la cámara baja paulatinamente hasta centrarse en el rostro de Silver, quien entona la canción The Bed y ella canta que se siente atada a una cama de hielo y empujada por fuerzas ajenas. El patetismo de la escena se intensifica con la intercalación de los primeros planos de los rostros de ambas figuras femeninas, quienes, de forma cómplice, se miran la una a la otra antes de que sus cuerpos sean intercambiados.

El uso del plano cenital y el movimiento descendente de la cámara, que nos descubre el primer plano del rostro de Silver, genera un proceso de identificación del espectador con la angustia del personaje. Se consigue así que el espectador explore el mundo interior de la sirena, lo que generalmente se ha omitido en los relatos literarios y cinematográficos protagonizados por esta criatura. La visión general del pseudoquirófano que ofrece el plano cenital deja paso progresivamente al examen minucioso y metonímico del cuerpo de la sirena mediante el movimiento de paneo de la cámara. Así pues, aparece un primer plano del rostro de la sirena y un plano detalle de la costura quirúrgica hasta terminar con la imagen del cirujano moviéndose al son de una música que simultáneamente Golden está tocando al piano en otro espacio, el departamento donde ambas conviven con los humanos.

Al no suprimir ningún aspecto y detalle de la escena, así como tampoco la vivencia de la sirena, que experimenta no solo la dolorosa amputación de su cola, sino también la supresión de su identidad y su mundo, Smoczyńska critica la materialidad a la que generalmente se ha reducido la imagen de la mujer en los discursos. A través de la combinación de largos y primeros planos, el uso del color azul que muestra el 
momento introspectivo de la protagonista en un ambiente cargado de frialdad, melancolía y tristeza y la canción que entona la sirena («seré empujada por el pasillo con mi vestido quirúrgico»), la directora representa un acto a modo de sacrificio donde la sirena desaparece - pierde la cola - y se convierte en una mujer humana con dos piernas y unos genitales que permitirán que Mietek quiera estar con ella. Se representa así el sacrificio y la pérdida del yo que supone ajustarse a la identidad femenina tal y como es definida por el sistema patriarcal.

Otra escena significativa en cuanto a la indagación de la intimidad femenina se produce cuando Silver, en la bañera, se arranca una escama de su cola que entrega al bajista, hecho que le provoca un pequeño sangrado a modo de su iniciación sexual y pérdida de la virginidad. Enseguida, el entorno blanco e impoluto del baño se tiñe de un tenue azul que nos traslada al escenario del club nocturno donde el bajista y Silver entonan la canción Take in your care («Cuida de mí») con un estilo electro-pop. Una panorámica de reconocimiento hace un pausado recorrido por la escena en aras de permitir al espectador fijarse en todos los detalles del escenario y en el punto de luz que un potente foco proyecta sobre la pareja (Fig. 11).

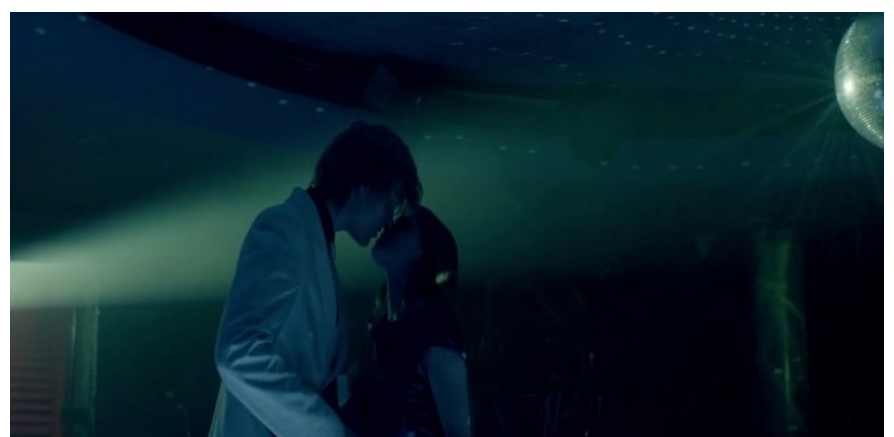

Figura 11

El movimiento de travelling circular o en arco permite que la cámara se desplace en círculo alrededor de los jóvenes, muy próximos el uno del otro. Se proyecta, así, una poética romántica en pantalla mediante el espacio, la ponderación de la subjetividad y la ensoñación experimentada por la sirena enamorada desde su ubicación inicial en la bañera. Esta intimidad se proyecta en el escenario a través del color, la luz y la música diegética.

La poética romántica, presente en la escenificación de Silver y Mietek, contrasta con otra escena donde aparece el tono melancólico y sombrío con el que su hermana Golden percibe el mundo humano fuera del agua, un mundo que hace peligrar su sueño de nadar hasta los Estados Unidos. Mientras los dos integrantes masculinos del grupo cuentan en la cocina el dinero conseguido gracias a las actuaciones erótico-musicales de las sirenas, Golden se abstrae en el baño, el único lugar doméstico donde puede estar en contacto con el agua y convertir sus piernas humanas en cola de pez. La cámara semisubjetiva nos muestra a la sirena de espalda y vemos lo que ella está contemplando en ese momento, asumimos su mirada (Fig. 12). Ella mira una pantalla colocada en la pared en donde aparecen unos fotogramas de idílicos y vírgenes entornos marinos. A continuación, un plano lateral y un movimiento panorámico de la cámara mimetiza el movimiento visual descendente que realiza Golden, desde la pantalla al inodoro.

El contraste producido entre la imagen del paraíso marino perdido en pantalla y la realidad más tangible, vinculada con lo escatológico, sumergen a la sirena en una 
ensoñación que cumple una evidente función evasiva. El espacio físico se vuelve a colorear de un intenso azul potenciado por el uso de la luz. Entonces el tiempo parece detenerse y todos se congelan en el departamento mientras que Golden, desnuda, se mueve entre ellos cantando sobre su aguda soledad y tristeza (Fig. 13). De nuevo, recogiendo todos los detalles, la cámara panorámica recorre pausadamente la cocina, el salón y la habitación donde Silver, también congelada, contemplaba embelesada a Mietek tocando el piano. La canción The housefly — «la mosca doméstica»—, entonada por Golden, remite no solo a su soledad y tristeza, sino también a la sensación de encierro y reclusión del personaje en el departamento. Poco después, vuelve a refugiarse en la bañera donde, en contacto con el agua, puede rememorar su existencia en el entorno marino y transformar sus piernas humanas en una tremenda cola de pez.

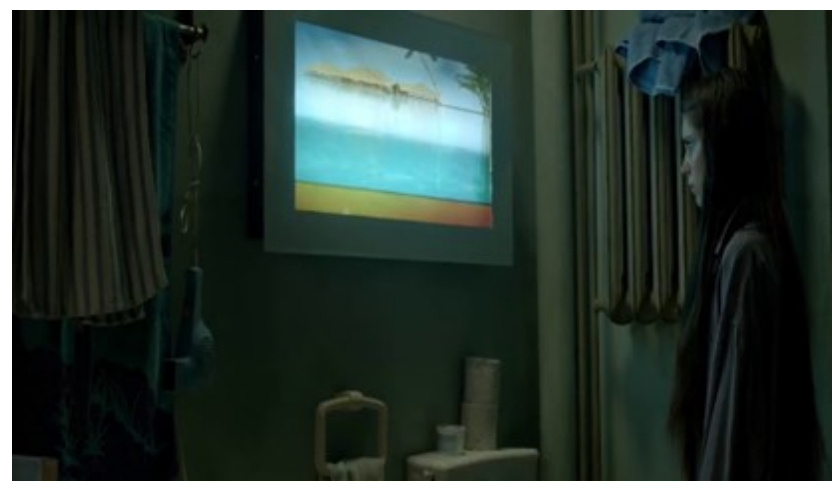

Figura 12

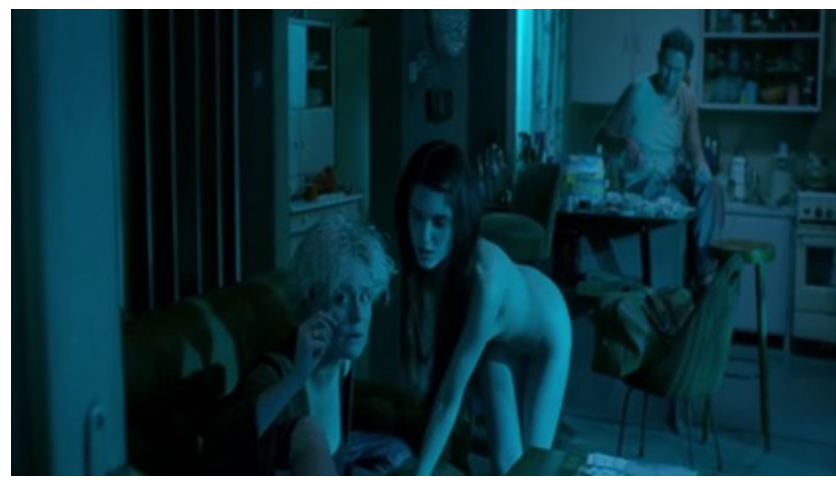

Figura 13

Estas escenas subjetivas representan situaciones oníricas ajenas a las leyes objetivas que rigen el mundo real de la diégesis puesto que el espacio, bañado por una significativa luz azulada junto con la música y la toma de imágenes congeladas, permiten las incursiones del espectador en la intimidad y en la propia percepción de las sirenas. En este sentido, De Lauretis y Mayorga analizan las prácticas fílmicas de autoría femenina $\mathrm{y}$, cuando se preguntan si hay un lenguaje cinematográfico específico de mujer o una estética propia de las cineastas, afirman que, en estas, lo pre-estético se convierte en estético. La praxis filmica femenina no se vincula con la belleza de las imágenes elegidas ni con la cuidada edición de sus tomas congeladas, sino que:

son las acciones de una mujer, de su cuerpo y de su mirada las que definen el campo de nuestra visión, la temporalidad y los ritmos de percepción, el horizonte de significado 
abierto del espectador. [...] Lo que la película construye - formalmente y con sentido estético- es un retrato de la experiencia femenina, de duración, percepción, hechos, relaciones y silencios que se perciben como incuestionablemente verdaderos (De Lauretis y Mayorga, 1992: 257).

En este contexto, la traducción de la intimidad psíquica femenina a la pantalla a través de los códigos cinematográficos se revela decisiva para acceder al mundo interior del yo femenino, evidenciando el tratamiento diferencial que Smoczyńska otorga a su sirena fílmica respecto al arquetipo literario tradicional recogido y proyectado en otras propuestas audiovisuales. No obstante, la complejidad psicológica femenina en el film se evidencia también en Krysia, la cantante del grupo de músicos, quien representa a la figura materna de las sirenas en una manifiesta correlación con la abuela retratada en el cuento de Andersen. De esta manera, la directora explora, como veremos, también la intimidad psíquica — los sueños - del personaje para analizar la relación madre-hija en pantalla.

\section{EL CONFLICTO MADRE-HIJA}

La evocación de la maternidad está muy presente en el film que nos propone Smoczyńska a través del personaje de Krysia, la cantante del grupo que realiza diversos espectáculos erótico-musicales junto a las sirenas. Recordemos que es ella quien inicia a las sirenas en el ambiente nocturno de la Varsovia de los años ochenta. En la primera escena, cuando Golden y Silver están a punto de hacer sucumbir bajo sus colmillos a los dos integrantes varones del grupo, frente a la orilla del río Vístula, escuchamos el chillido atronador de Krysia. Su acto imposibilita la acción sanguinaria de las sirenas y nos traslada inmediatamente a las luces y brillos del club donde trabaja. Así pues, la cantante, de mediana edad, desvía a las adolescentes sirenas de su instinto primigenio y las introduce en el mundo de la explotación sexual donde serán sometidas a la objetivación masculina. Precisamente, después de que Krysia presente a las sirenas al mánager del club, estas serán sometidas al reconocimiento físico del viejo propietario, quien procede con sus dedos a hurgar en la hendidura que, a modo de genitales, presentan las criaturas marinas en sus colas. La cantante, que representa la figura materna en el film, somete a las sirenas a unos parámetros sociales y culturales que ella misma ha asimilado y experimentado. Como explica Silvia Tubert (1996: 27): «La madre señala el lugar en el que las mujeres no son sujetos; luego, la madre como sujeto existe allí donde las mujeres no pueden constituirse como tales. Pero esta ausencia no se debe a su localización cósmica en un espacio maternal situado más allá del tiempo paterno sino a su localización social en una cultura patriarcal».

En este sentido, Krysia adquiere reconocimiento y cierta autoridad dentro del grupo musical en tanto que ratifica unos valores patriarcales manifiestos también en el club nocturno. Ella es «porteadora de los valores del Padre» (Sau, 2004: 108), puesto que relega a las sirenas a la materialidad grotesca y erótica de sus cuerpos siendo conceptualizadas como objeto de la mirada voyeur masculina. Krysia somete el cuerpo femenino al deseo del Otro - del varón - y lo contempla como un mero producto de compra-venta del cual todos en el grupo obtienen réditos económicos. Como $\mathrm{M}^{\mathrm{a}}$ Isabel Rodríguez (2007: 338) explica, desde la Antigüedad, las sirenas han sido circunscritas al cuerpo, la materia y la naturaleza, «como símbolos de la atracción sexual, la voluptuosidad y el vicio de la carne». 
A este respecto, una escena significativa se produce mientras Krysia y las dos sirenas adolescentes, vestidas de capitana de avión y azafatas respectivamente, están preparándose en el camerino para el espectáculo. Ellas están mirándose ante el espejo del camerino (Fig. 14) y la cantante aconseja a las jóvenes que se tapen un poco porque deben dar al público (masculino) algo que anhelar, algo que desear. De este modo, Krysia, dotada de cierta autoridad materna frente a las sirenas, perpetúa los parámetros patriarcales definiendo a la mujer en función de su cuerpo y siempre buscando satisfacer el deseo ajeno. La mujer solo existe en la medida que es objeto de deseo y no sujeto.

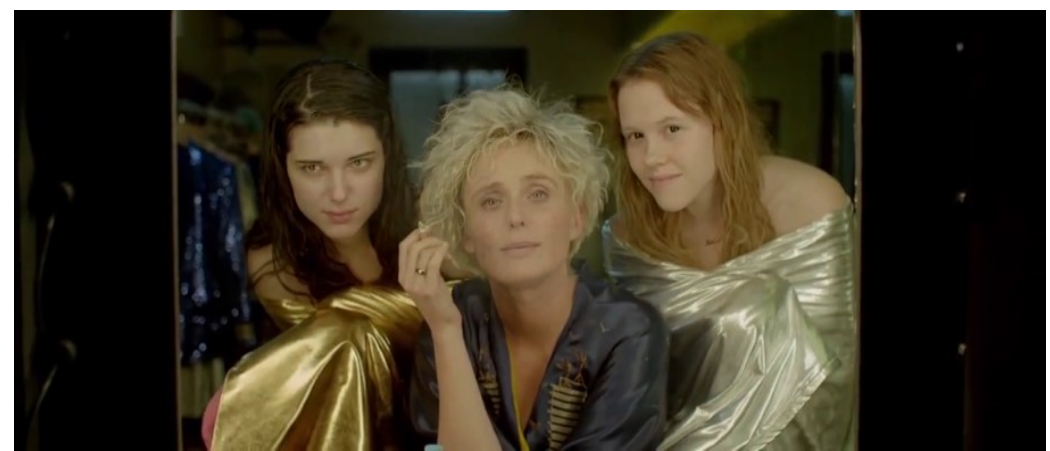

Figura 14

La maternidad, a través de la relación madre-hija, aparece como lugar de la pérdida de la condición de sujeto en el sistema dominante tal y como explica Luciana Percovich (1996: 225-258). Esta teórica propone así un sistema alternativo en el que se articule el propio deseo y el reconocimiento de la subjetividad de la hija, reivindicando unas prácticas maternas eficaces que no sean repetidoras o amplificadoras de los valores dominantes y contenidos ajenos. Estas nuevas prácticas deben de ser estimuladoras de la individualidad y el cambio, alejándose así de una maternidad patriarcal, falsa o «impostada» en términos de Victoria Sau (1994: 87-113).

En cuanto a la relación madre-hija, Smoczyńska recurre de nuevo a la exploración de la intimidad psíquica en pantalla y al detalle de la imagen para conseguir una obra de gran potencia visual, llegando a crear escenas tremendamente perturbadoras. Una de ellas se produce en la semioscuridad de la habitación del departamento donde todos conviven. En ese ambiente taciturno y opaco, solo atenuado por los reflejos lumínicos que llegan desde la calle a través de las ventanas, Krysia está manteniendo relaciones sexuales con el baterista del grupo. De repente su mente se evade y sueña que ella, también sirena y con una cola de pez, está en otra habitación luminosa y abierta, dentro de una cama, amamantando a Golden y Silver. El espacio evocado es intencionalmente minimalista para destacar la escena maternal y la luminosidad, incrementada por los destellos de la bola de espejos o de discoteca, intensifica unos colores blanquecinos y tenues que son amenizados por las burbujas que caen alrededor de las tres féminas. Se recrea así el retorno al seno materno vinculado con la protección y cuidado de la madre.

De este modo, el espacio semioscuro, erótico y sexual del departamento se torna en un espacio luminoso y sacralizado por la vinculación con lo materno, pero también grotesco a causa de la repulsión que provocan las tres criaturas con cola de pez. La perpetuación y asimilación de los valores patriarcales por parte de la madre y la hija persiguen el reconocimiento y la búsqueda constante de la legitimidad otorgada por el varón. Este es el origen de los conflictos y las tradicionales competencias femeninas, 
también entre madre e hija, ${ }^{4}$ que aparecen representados en los discursos artísticos como en la Electra de Eurípides, tragedia llevada al cine por Michael Cacoyannis en 1962.

\section{CONCLUSIÓN}

En la actualidad, Smoczyńska, antigua alumna en la Escuela de Cine Krzysztof Kieślowski en la ciudad de Katowice, es una de las escritoras y directoras de cine y televisión polacas más prometedoras y prolijas del momento. En The Lure la directora acentúa la rutina de unas sirenas que, dedicadas a actuar en números musicales semidesnudas en la Varsovia de los años ochenta, establecen una dialéctica con la tradición literaria a partir de los textos homérico y andersiano. Al poner en primer plano elementos como el punto de vista femenino, la objetivación del cuerpo de la mujer y la vivencia de la sexualidad en sus protagonistas, Smoczyńska permite la aparición ante los ojos del receptor de un yo femenino, generalmente omitido en los relatos literarios y cinematográficos donde la sirena es protagonista. Consigue así denunciar y cuestionar la identidad femenina tal y como ha sido construida tradicionalmente por los discursos artísticos. En este sentido, no podemos obviar que en la filmografía de Smoczyńska, como en Aria Diva (2007) y Fuga (2008), se advierte un sesgo de género y una importante impronta kieślowskiana - recuérdese la valiosa trilogía que el cineasta nos dejó en los años noventa: Azul (1993), Blanco (1994) y Rojo (1994)—, sobre todo en cuanto al uso de la cámara, la música y el color como mecanismos que traducen la intimidad de sus protagonistas.

Sin duda, con su film The Lure (2015), Smoczyńska se aleja marcadamente de las traslaciones filmoliterarias realizadas acerca de la mítica y popular figura de la sirena, generalmente recreada como objeto de deseo y bajo la mirada masculina dentro y fuera del relato cinematográfico. El quehacer cinematográfico de Smoczyńska se ubica dentro de lo que Bárbara Zecchi (2014) ha llamado «ginocine» a partir de cómo ciertas cineastas deconstruyen los patrones hegemónicos en torno a la imagen de la mujer en pantalla.

\section{OBRAS CITADAS}

Andersen, Hans Christian (2017), La sirenita y otros cuentos, Madrid, Losada.

Boccaccio, Giovanni (1983), Genealogía de los dioses paganos, eds. $\mathrm{M}^{\mathrm{a}}$ Consuelo Álvarez y Rosa $\mathrm{M}^{\mathrm{a}}$ Iglesias, Madrid, Editora Nacional.

Cana, Fernando (1992), Iconografía del románico burgalés, Madrid, Universidad Complutense de Madrid.

Cirlot, Juan Eduardo (1997), Diccionario de símbolos, Barcelona, Siruela.

Cixous, Hélène (1995), La risa de la medusa. Ensayos sobre la escritura, trads. Ana M. Moix y Myriam Díaz-Diocaretz, Barcelona, Anthropos.

${ }^{4}$ M. ${ }^{a}$ Ángeles Hermosilla (2003: 337-358), que ha estudiado la relación madre e hija en la narrativa española contemporánea escrita por mujeres, señala que la figura materna, aunque se ha enriquecido con nuevos matices en la novela de las últimas décadas, siempre ha estado marcada por una situación de conflicto en su relación con la hija debido a que reproduce en esta la misma situación de opresión y discriminación que ella sufre dentro del patriarcado. 
De Lauretis, Teresa y Susana Mayorga (1992), «Repensando el cine de mujeres. Teoría y estética feminista», Debate Feminista, 5, pp. 251-277.

De Sevilla, Isidoro (1951), Etimologías, trad. Luis Cortés y Góngora, Madrid, Biblioteca de Autores Cristianos.

Dijkstra, Bram (1994), Ídolos de perversidad. La imagen de la mujer en la cultura de fin de siglo, Madrid, Debate.

Elvira, Miguel Ángel (2008), Arte y mito. Manual de iconografia clásica, Madrid, Sílex.

García Gual, Carlos (2014), Sirenas. Seducciones y metamorfosis, Madrid, Turner Noema.

Gingold, Michael (8 de febrero de 2017), «Exclusive interview: director Agnieszka Smoczynska on the allure of The Lure», RueMorgue, $<$ https://rue-morgue.com/exclusive-interviewdirector-agnieszka-smoczynska-on-the-allure-of-the-lure/>.

Hermosilla, M. ${ }^{a}$ Ángeles (2003), «La relación madre e hija en la narrativa española contemporánea escrita por mujeres», Lecturas, imágenes: revista de poética del cine, 2, pp. 337-358.

Homero (1991), Odisea, ed. Antonio López Eire, Madrid, Espasa Calpe.

Horacio, Quinto (2002), Epistolas. Arte Poética, trad. Fernando Navarro, Madrid, CSIC.

Irigaray, Luce (2009), Ese sexo que no es uno, trad. Raúl Sánchez Cedillo, Madrid, Akal.

Isart, $\mathrm{M}^{\mathrm{a}}$ Consolación (1994), «Ulises en el mundo cristiano del siglo II», Fortunatae: Revista canaria de Filología, Cultura y Humanidades Clásicas, 6, pp. 25-42.

Lagarde, Marcela (2012), «Enemistad y sororidad: hacia una cultura feminista», en Marcela Lagarde, El Feminismo en mi vida. Hitos, claves y topías, México, Instituto de las Mujeres del Distrito Federal, pp. 461-491.

Latini, Brunetto (1202), Libro del tesoro [Manuscrito s. XV], $<$ http://bdh.bne.es/bnesearch/detalle/bdh0000026321>.

Maceiras, Andrea (2014), «La vieja sirena: la reinterpretación del mito de la sirena en la novela de José Luis Sampedro», Amaltea. Revista de mitocrítica, 6, pp. 207-217.

Martín, Joaquín Carlos (2010), «La mujer fatal y los hombres fatalizados», en Ángel Luis Montejo (coord.), Sexualidad, psiquiatría y cine, Barcelona, Editorial Glosa, pp. 35-44.

Martínez, Manuel (2003), Los títulos literarios, Madrid, Nostrum.

Molina, Francisco (2017), «La vida amorosa de las Rusalki», Liburna, 10, pp. 101-142.

Mulvey, Laura (2001), «Placer sexual y cine narrativo», en Brian Wallis (ed.), Arte después de la Modernidad: Nuevos planteamientos en torno a la representación, trad. Carolina de Olmo y César Rendueles, Madrid, Akal, pp. 365-377.

Mussies, Martine (2018), «Frankenstein and The Lure: Border crossing creatures through a feminist lens», Foundation, 47, 130, pp. 47-58.

Ovidio, Publio (2002), Las metamorfosis, trad. Ana Pérez Vega, Alicante, Biblioteca Virtual Miguel de Cervantes, $<$ http://www.cervantesvirtual.com/obra/metamorfosis--0/>.

Pardo, Pedro Javier (2010), «Teoría y práctica de la reescritura filmoliteraria (A propósito de las reescrituras de The Turn of the Screw)», en José Antonio Pérez Bowie (ed.), Reescrituras filmicas: nuevos territorios de la adaptación, Salamanca, Ediciones Universidad de Salamanca, pp. 45-102.

Percovich, Luciana (1996), «Posiciones amorales y relaciones éticas», en Silvia Tubert (ed.), Figuras de la madre, Madrid, Cátedra, pp. 225-258.

Rich, Adrienne (1972), «When We Dead Awaken: Writing as Re-Vision», College English, 34, 1 , pp. 18-30.

Rodríguez, M. ${ }^{a}$ Isabel (2007), «La música de las sirenas», Cuadernos de Arte e Iconografía. Fundación Universitaria Española, XVI, 32, pp. 333-356.

Salecl, Renata (2002), (Per)versiones del amor y del odio, México D.F., Editores Siglo XXI.

Sau, Victoria (1994), «La maternidad: una impostura», Duoda. Reviste d'Estudis Feministes, 6, pp. 87-113.

Tubert, Silvia (1996), «Introducción», en Silvia Tubert (ed.), Figuras de la madre, Madrid, Cátedra, pp. 7-37. 
Widdowson, Peter (2006), «Writing back: Contemporary Re-visionary Fiction», Textual Practice, 20-3, pp. 491-507.

Zecchi, Bárbara (2014), Desenfocadas. Cineastas españolas y discursos de género, Barcelona, Icaria. 